\title{
(Gender) partnership as a transforming paradigm for development in the Church and society
}

\begin{abstract}
Authors:
Ester Onwunta ${ }^{1} \dagger$

Karel T. August ${ }^{1}$

Affiliations:

${ }^{1}$ Department of Practical

Theology and Missiology,

University of Stellenbosch,

South Africa

Note:

In memory of Ester Onwunta, who passed away in 2011.

This article is published in the section Practical Theology of the Society for Practical Theology in South Africa.

Correspondence to:

Karel August

Email:

kta@sun.ac.za

Postal address:

Faculty of Theology, 171

Dorp Street, Stellenbosch

7600 , South Africa

Dates:

Received: 18 Apr. 2011

Accepted: 27 Sept. 2011

Published: 18 Apr. 2012

How to cite this article:

Onwunta, E. \& August, K.T.,

2012, '(Gender) partnership

as a transforming paradigm

for development in the

Church and society',

HTS Teologiese Studies/

Theological Studies 68(2),

Art. \#1065, 9 pages. http://

dx.doi.org/10.4102/hts.

v68i2.1065
\end{abstract}

(C) 2012. The Authors.

Licensee: AOSIS

OpenJournals. This work

is licensed under the

Creative Commons

Attribution License.
This research article made the case for (gender) partnership as an integral part of effective people-centred participatory development theory. Over the years, development has been taught and practiced in different ways. In the contemporary African context, it is a term that is frequently used and even misused by many people and organisations that are involved in development programmes, which truncate rather than transform the people and communities they claim to develop. This article presented a brief survey of some definitions and views on development and argued for a holistic approach to development, one which is anchored on partnership as an essential element in God's mission; that is, the missio Dei. It highlighted the reasons for, ideals of and obstacles to true partnership in development.

\section{Introduction}

Development is about change - a change that affects people and things in society. Therefore:

social change is at the heart of the mission of the church where both men and women, being equally created in the image of God, benefit and are restored to full humanity. (Haddad 2003:430)

Consequently, development is a process of social change in which gender is a strategic marker and partnership is central to any discussion on the mission of the Church. In pursuing such a discussion, the task before contemporary African theology and development experts is to opt for the understanding of mission as 'church with others' and 'missio Dei', as expounded by David Bosch (1991). This new understanding is an attempt to locate mission in Africa as both a holistic and an engaging enterprise. Therefore, the aim of this article is to highlight the point that, in the African setting (cf. Bediako 2004:104), the role of women (the other) in development, and therefore partnership, is essential if development is going to be effective.

This point is at the heart of the mission of God - the missio Dei - and underscores the necessity for sound theological framework in the Church's engagement in any development process in Africa. As Bosch (1991) explains:

Since God's concern is for the entire world, this should also be the scope of the missio Dei. It affects all people in all aspects of their existence. Mission is God's turning to the world in respect of creation, care, redemption and consummation. (p. 391)

To this end, Rose Teteki Abbey (2001), a Ghanaian theologian, has suggested that African theologians need to examine African traditional metaphors of God, which are inclusive and have a sense of partnership in them. She has therefore come up with an example from the Ga people of southern Ghana, arguing that:

God is traditionally known as Ataa Naa Nyonmo. This name does not only mean Father Mother God, it also implies and stresses maleness and femaleness of God. Seeing God as Father and mother emphasizes the creative power of God as opposed to the macho image which gives the idea of controlling power. Although the Ga Christians have adopted and use this name, its etymology has little impact on their image of God. (p. 141)

Herein lies the challenge: How can our understanding of God engender our sense of partnership in the development of human society? The point we are making here is that a holistic development of human society can only be realised through the partnership of women and men. As such, our argument is that ministry as partnership is necessary, not only for the Church as koinonia:

but also to enable the Church to provide a model for society, which is grappling with the same issues of shared responsibility and accountability between its leaders and its people. (Kanyoro 1996b:156)

This is especially true in Africa, where political and ecclesiastical leaders focus, all too frequently, on their own needs and are heedless of the common good of both sexes. This leads us to the subject of this article, which is the meaning of development in the Church and society and the option of partnership. 


\section{What is development?}

Development is obviously a complex and slow-moving process involving people, on the one hand, and the factors of production and organisation on the other. For Burkey (1993:39), 'It is obviously not a simple matter of an investment project here and a training programme there'. So there can be no fixed and final definition of development; but we can make suggestions of what development should imply in particular contexts. Thus, in the context of gender and development in South Africa, Haddad (2003) has clearly stated that:

In order for the church to play any meaningful role in the development of communities, there need[s] to be a sound theoretical understanding of 'development'. Development, however, is not neutral but is a gender issue. Theoretical issues of gender and development need to be understood within the context of extreme poverty experienced by poor and marginalized South African women. (p. 427)

Ingeneral terms, theultimatepurposeand practical foundation of development involves structural transformation of people and objects. As also observed by Bronkema, Lumsdaine and Payne (1998:110), development needs to be concerned with building and cultivating human persons and communities as wholes.

\section{For that reason, Carmen (1996) has cautioned that:}

It is demeaning, dehumanizing and, therefore eminently antidevelopment to define people by what they are not: ignorant, illiterate, poor, powerless ... Development starts from the other end: from the power in the powerless, from the literacy (and oracy) in the illiteracy, from the ability in disability, from the formal in what the owners of development refer to as non-formal and informal. In other words, it sets out from where people are. (p. xii)

In a similar vein, Wilson and Ramphele (1989) have this to say:

... genuine development work is that which empowers people; which enables them to build organizations that, like a hydroelectric dam, pool their resources and generate power where previously there was none. (p. 262)

Another definition that affirms the above is one which was issued by the United Nations (1982) in their report on development:
... to connote the process by which the efforts of the people themselves are united with those of the government authorities to improve the economic, social and cultural conditions of communities, to integrate these communities into the life of the nation and to contribute fully to the national progress. This complex of processes is, therefore made up of two essential elements: the participation of the people themselves in an effort to improve their living, with as much reliance as possible on their own initiative; and the provision of technical and other services in ways which encourage initiative, self-help and make those more effective. (n.p.)

In effect, it is development that is participatory, self-reliant and people-centred. The participation of people themselves in their own development is both an essential part of human growth and a process whereby the people themselves become aware of, and understand, their problems and the social reality within which they live in order to effect lasting change at grassroots level themselves (August 1999:24). Through this process of conscientisation, people become aware of their own needs. They can embark upon self-reliant ventures where they themselves feel that they are contributing the maximum human, material and financial resources relative to their ability.

Hardly can we achieve this developmental success in our human communities without the partnership of men and women. But as we know, the road of partnership between women and men is not easy and there are still many obstacles to overcome. Indeed, there are still many chains to be broken as we strive to foster and authenticate partnerships between men and women which build and sustain gender justice in the Church and the wider society. According to SheerattanBisnauth $^{1}$ (2004):

For decades women have been working to educate the world that gender injustice is a critical issue in underdevelopment and that it hinders peace and justice. Yet today, despite the great threats to life and growing instability, gender justice is still marginal to many people who hold power in church and society. We are living in a world where there is growing perception that conservative values and notions are rising and efforts to address gender injustices are being increasingly challenged. Gender justice is one of the slowest developments in the world (including the church). (p. 7)

How do we wriggle ourselves out of the shackles of gender injustice in development? How can we engender the spirit of true partnership between men and women in order to deal with the menace of gender injustice in church and society? What should be the ideals of such a partnership? What problems should we be aware of as we seek to engage in the process of building a true partnership between men and women in the Church and in communities in Africa and beyond? These are some of the questions on which we reflect below.

\section{Why partnership?}

One may ask: Why partnership? It is obvious that in our world today partnership is needed if we must move forward as a human community in our social, political, economic and religious lives. Below are some of the reasons why we should engage in partnership. Edet and Ekeya (1989:9) have suggested that 'humanity will keep its image and likeness of God if both male and female work as a body'. But many factors try to deny women their equal worth as people created in the image of God.

Nussbaum (2000:1) observed that women in much of the world lack support for the fundamental functions of a human life. In many nations, women are not fully equal under the law: they do not have the same property rights as men; unequal social and political circumstances offer women unequal human capabilities. To bridge this gender divide calls for an understanding of the essence of partnership.

1.Patricia Sheerattan-Bisnauth is the Executive Secretary of the Department of Partnership of Women and Men of the World Alliance of Reformed Churches (WARC). 


\section{It is God's purpose from creation}

God's plan of differentiation of his creatures was not meant to be a disadvantage to others, but was meant to enrich one another. The whole of creation is immersed in community and interdependence. Beauty and splendour are manifested in the partnership of the created beings. God intended it so and the people created in God's image (women and men) are thus to live in the spirit of partnership. Unfortunately, one of the legacies of the Enlightenment paradigm in human history is the enthronement of 'autonomous individualism' and the neglect of community as a way of life. Autonomous individualism was not translated into gender equality with the result that patriarchalism affected society throughout the 19th century, as well as the first half of the 20th century, leaving the Church, for most of its structures, practices and mission, very male-oriented. ${ }^{2}$ Women have been the casualties of this development and it is therefore time we realised that because both men and women are baptised in Christ and are gifted by the spirit of mission and ministry, 'partnership of women and men, ordained or not, is the true image of the church of Christ' (Oduyoye 2001:86). The gifts of women and men are both necessary if the Church is to be whole and is to be the light of Christ to the world. As Rakoczy (2004) puts it:

Partnership means working together, sharing responsibility, calling forth each other's gifts, caring for the life of the community. It does not mean excluding men in order to affirm women's gifts. (p. 224)

This is why this article is pressing for partnership as a way of regaining our common humanity, restoring our community and also transforming God's creation, of which we are part. Mutuality is relevant only where partners recognise and respect each other; mutuality does not recognise paternalism. Once women are seriously acknowledged as partners, as the body of Christ, then we can build a new Church. We agree with Ramodibe (1989:18) when she points out that men and women need to cooperate on the basis of mutuality. We need mutuality to build a new human community where everybody belongs.

\section{To foster community change}

People who work in partnership can have an increased sense of power and determination to initiate change based on the knowledge they gain from the vastly different experiences and perspectives of their own members. Partnership can also put groups in a unique, powerful position to solve community problems in fighting crime and building developmental projects. One of the authors of this article, Ester Onwuta, remembers how, as Secretary of the local church Women's Guild $^{3}$, she helped the Guild create awareness of the acute housing problem for the junior church workers, mobilising the men and women in the church to embark on a housing project which saved the community of believers from shame and unnecessary financial spending on rent. Partnership

2.The argument here is about 'one of the legacies of the Enlightenment', in order not to ignore the impact of patriarchal society on women's development.

3.The Women's Guild is an arm in the Presbyterian Church of Nigeria that embraces all the women. It often is called the Mothers' Union or Women's Fellowship in other churches. through collaboration with men can enable women do much for the Church and community.

Without partnership, it is almost impossible for any collaboration to take place. The old Israelite Prophet, Amos (Am 3:3), put it succinctly when he asked 'can two walk together without agreement?' Allen (1999:5) argues that the most effective way for the Church to effect social change in an urban context is to be what he labels a church with the city. This approach is incarnational and encourages the Church to enter into the life of the community and become partners with the community in addressing its needs. Yet, this kind of partnership requires sacrifice and risk that brings new challenges such as race, socio-economic differences, cultural and religious pluralism, and gender issues into the limelight.

However, we cannot build relationships without the understanding of our potential partners, and we cannot achieve that understanding without a form of communication that goes by way of conversation. Our mutual interdependence makes collaboration an imperative for mission and development. Mission, above all, means sharing: it is not that we have something to give and others have something to receive, but that there should be a 'fair balance' (2 Cor 8:13-14). The following story might be helpful in buttressing this point:

Some years ago, a group of British development workers was visiting the Sudan. They were told that the Sudanese pastors were in need of bicycles to make their rounds to the churches, and so they offered the church several hundred bicycles. The church was delighted with this offer, and asked what the church in the Sudan could do for Britain. 'Nothing', was the reply. 'Then we cannot accept these bicycles'. (Wickeri 2004:162)

Sharing in mission is a two-way street that involves both selfemptying and empowerment. Even in building relationships, we must accept that others have something to offer, for no one has the monopoly on knowledge. With this in mind, we find the principle of reciprocity to be an important tool in building partnership and developing democracy.

\section{To strengthen democracy}

Partnership helps to foster democracy. Politics and democracy are somehow interwoven, especially in the way we practice democracy in our context.

\section{According to Kabeberi-Macharia (2004):}

Despite the increasing popularity of the concept and practice of democracy, engendered democratic governance is yet to be achieved. One reason being that democracy as we know it, still falls almost exclusively within the domain of politics which comes within the traditional definition of politics which is characterized as male dominated, specific to the 'public sphere' and therefore not necessarily women friendly. Again inequities between men and women are glaringly obvious in governance institutions with the balance heavily tilted towards participation of men more than women in key decision-making positions. (p. 96)

Gender equality in governance is necessary to ensure that women have equal economic, social and political opportunities. The opinions and perceptions of women and men must be taken into account in formulating any decision 
or carrying forward any strategy (Kabeberi-Macharia 2004:97).

The views we are advocating here have implications for not only the nation - state, ethnic and tribal politics at various levels in Africa - but also for the state of women in democracy. Stressing the need to cultivate and deepen democracy and tolerance through dialogue and partnership amongst all citizens, both female and male, Eyo (1995) further asserts:

It is only in such a culture that leaders are tested and retained or thrown out according to the will of the people. It is only in such a culture that mistakes are made and corrected without social upheaval. It is only in such a culture that people are groomed to be tolerant of people of another language, colour, sex, ethnic group or clan, and to be able to give and take in periods of triumphs and failure. It is only in such a culture that Nigeria for instance can evolve to become a viable polity that inspires loyalty and patriotism. (p. 11)

The question is how a nation can enjoy democracy when its women are not allowed either to express their opinions or to participate or even contribute in matters affecting them? In a country where the majority of the population consists of women who face violence, poverty, illiteracy and inequality, how can democracy succeed? Most women hear about democracy but have never experienced it, either in their homes or in society at large. The way forward is thus only through genuine partnership.

Talking about polity, there is no gainsaying the fact that many of our Church structures are still authoritarian in practice and exclusive of some members, especially women. We need to democratise these structures so that men, women, boys and girls would freely unfetter their God-given talents and also participate in building a better society to God's delight. But as long as we fear and neglect partnership by excluding women from the key positions of leadership, autocracies and exclusions will continue to keep resources untapped, both in the Church and in the wider society.

\section{To foster peace}

Peace is both a condition for and a result of effective development. Without peace, we will find it difficult to bring about development; yet, the goal of development is to produce peace (Shalom). For instance, effective and fruitful development can be elusive if there is war in the village, yet in the midst of the war we need to identify with the suffering people in order to bring peace and hope to them. So, partnership is a fundamental component in the process of peace building. Peace building maintains human infrastructure for relationships that are harmonious, synergistic, cooperative, responsive and mutually beneficial. When people are divided by their differences, the patterns of relationships reinforce separation, fragmentation and divisiveness. Partnership between men and women provides a way of creating bridges across the chasms of our differences.

\section{To foster innovation}

Through the process of partnership we will be able to create our world and its future as we connect with one another, sharing knowledge and know-how and building relationships. When we consciously focus attention on 'questions that matter' - for our organisations and communities - we are contributing to the evolution of the knowledge that we need to co-create the future. We grow what we know individually and collectively using possibilities for mutual insight, innovation, and action that are already present, if only we are ready to look. The innovative possibilities of the future can only be realised in our communities, nations and the entire world if we are willing to partner with one another. And all the talk about African Union, the African Renaissance or the much-announced 'African century' becomes viable only if we can engage in innovative partnership. In order to understand and achieve better results in the struggles of our lives, church and communities, we will need to work in partnership with others, including women.

\section{Ideals of partnership}

There are a number of challenges one has to be on the lookout for, and be prepared to meet, for partnership to achieve its goal. Some of these challenges are mentioned and described in the subsections below.

\section{Equality}

Equality is one of the end products of the search for truth. When that truth is actively sought by women and men in the atmosphere of justice, it brings with it an even greater spiritual freedom (Kopas 1986:192). What this means is that there can be no freedom for any of us until there is freedom for all of us. Therefore, as long as women are not free to relate with men as equal partners in human enterprise, the freedom and progress that men seek will also remain elusive. According to Eme (2004:6): '... gender justice is a necessary condition for social progress especially in a world where women have been grossly exploited, alienated, hated, dehumanized and psychologically devastated.'

The spirit of equality in partnership can restore women's selfworth, which has been long denied by age-old gender injustice. We must repeat here that equality in partnership does not mean unhealthy rivalry but mutuality. And mutuality means that humans have a mission to one another. It is mutuality that makes development and progress possible in the sphere of inter-human relations. Mutuality and participation strengthen the life of the community and empower men and women in the struggle for a better human society. And for women, 'community is destroyed where there is no equality and mutuality' (Oduyoye 2001:85). Working as partners with one another requires that we begin with an affirmation of responsibility, solidarity and mutuality, both in the mission to humanity and our articulation of that mission. Otherwise, the whole process will sink into parallel monologues, never meeting at any point (Thangaraj 1997:58).

\section{Transparency}

Effective partnership thrives in an atmosphere of transparency. Transparency requires that we approach and deal with one another with trust and openness. True partnership does not have any room for hide-and-seek 
games. Rather, it eliminates suspicion by opening the door for joint ownership of problems and solutions. Men need to be open, just as women should have nothing to hide.

\section{Love and dignity}

Love is fundamental in partnership. It is the virtue that causes us to engage in any human enterprise, not for what we shall get but for what we shall give for the success of it. This love is reciprocal, just as partnership is. It is known in selfgiving and sacrifice. This is the type of love that Christian theologians call agape [Godly love]. Without it, all our efforts will amount to an effort in self-praise and emptiness. Men cannot engage in meaningful partnership with women if they do not have this Godly love.

Every person has something in themselves that makes them intrinsically human. This is the image of God which validates the humanity in us and, as such, deserves to be honoured and respected and not violated at any given time or place. As Peskett and Ramachandra (2003) explain:

There is no life so degraded, debased or impoverished that it does not deserve respect and is not worth defending with zeal and conviction. What finally makes a society worth living in is not the amount of consumer goods available in shopping malls, nor the effectiveness of its social welfare schemes, nor even the lack of discrimination in employment and education but the sense all people should have of being valued and appreciated by their neighbor. (p. 39)

In this case, partnering with women demands that they be treated with respect and their dignity upheld. Gone are those days when it was popular to say that 'women are to be seen and not to be heard'. Just as their physical presence counts, their voices should count even more. Our task is to listen to these voices so that our corporate lives can be further enriched.

But the fact is that many people - perhaps the majority today do not have the means which would enable them to take their place in an effective and humanly dignified way:

They have no possibility of acquiring the basic knowledge that would enable them to express their creativity and develop their potential ... their dignity is not acknowledged in any real way, and sometimes there is even [an] attempt to eliminate them from history through coercive forms of demographic control which are contrary to human dignity. (Powers 2003:119)

This is the situation in which many women find themselves. True partnership involves respect for other people and caring about their physical, mental and emotional well-being. We need to show that we care and that we are not simply exploiting one another. According to Daly (1994):

a second principle in Feminist Ethics is respect for life in whatever form it appears. Whether fetal life, the life of a friend, one's own life, the life of one whose intentions contradict one's own, or the life of a cow, it is worthy of respect and nurture. (p.9)

\section{Diversity}

Both at the root of and implied in the concept of partnership is the idea of diversity. According to McClure (1995:84) people live within certain 'frames'. Each individual has his or her own 'frame of reference'. Asserting the uniqueness and importance of our frames and how we get a 'footing' in a conversation, or how we hold on to our own footing, is very important. Sometimes we are content to fit into the frames provided by others. In a round table conversation, however, it is important that each member be given the opportunity to both resist and change the frame for discussion.

When such language is heard, it also empowers others to resist or change the frame. It means more than one voice, one opinion, one ideology and even one understanding about something. Ndungane (2004) writes:

What is at issue in our world today is whether one world view, one political stand point, one theological stance, one cultural perspective, overrules, is right, can assert dominance, and renders all other views inferior and illegitimate. Can we instead learn to comprehend that none of us has the monopoly on knowledge and understanding? More than that, our lives are enriched and our horizon expanded when we encounter other, authentic, expressions of human life, culture and spirituality. (pp. 162-163)

As brothers and sisters, we must face the call to develop an ethic of being 'together-in-difference'. The whole essence of partnership is defeated when we cease to entertain more than one view or understanding about how things are, or how things should be done.

\section{Accountability}

By the very structure of our existence, we are beings that are in a 'partnership' mode of existence. We are those who go forth from ourselves and back to ourselves in our reflexive consciousness, interpret ourselves and, with a sense of accountability, take responsibility for our actions and ourselves. We are those who go forth from ourselves to others in our cultural creativity, interpret the world of peoples and cultures around us and, with a sense of accountability, take responsibility for others and our world. We are also those who go forth from ourselves to the natural world around us, interpret it and take responsibility for it. Thus, the mission of humanity is to take responsibility for ourselves, others and the world. It is, briefly, to say 'yes' to Cain's question: Am I my brother's (or sister's) keeper? (Thangaraj 1997:53). Put in another way, it is to accept that I am because others are which is the meaning of the very popular traditional African expression of Ubuntu.

Solidarity is a check on 'solo' responsibility. This is because, without solidarity, responsibility has the danger of implying that it is something we do for others: we take responsibility for others (Thangaraj 1997:53). This is the problematic element in responsibility. We already know that human history is replete with tragedies resulting from humans taking responsibility for others. Part of the problem of our present world is the arrogance of the West, which derives from the socalled missionary and political doctrine of 'Manifest destiny' (Bosch 1991:298-300). Indigenous peoples and slaves were, almost without exception, treated as children and minors, 
especially in colonial times. Solidarity in partnership does not permit this type of unwarranted unilateralism, whether in domestic or public affairs. In large parts of Africa, as in many other societies, men have done incalculable harm to women because they were taking responsibility for them. Even parents can destroy their children's capabilities by overbearingly taking responsibility for them. We can no longer afford to continue in this type of world if we are to be in partnership with one another. Thus, we cannot define the mission of humanity in terms of responsibility alone. To this end, we agree with Thangaraj (1997:53), who argues that if the mission of humanity is an act of responsibility, it must be fulfilled in a mode of solidarity and accountability.

\section{Problems of partnership}

Yet, to achieve ideal partnership, many problems have to be dealt with accordingly. Some of these obstacles on the way to true partnership are described in the subsections below.

\section{Fear}

In partnership people need to trust one another. But if we want to develop trust, we first have to show that we ourselves can be trusted. Sometimes men fear that if women know what they know, they (men) will be out of business. A respondent in Baillie (2002:88) expressed this clearly: 'if you put women in the job the men will do nothing.' Many people fear and worry about the future more than the present. In the area of partnership, lack of trust produces the greatest fear.

But men who are worth their calling are not afraid of others, including women. Kennedy (1995) reminds us of the statement by the Nobel Prize Laureate, Aung San Suu Kyi of Burma (Mayanmar), in her key note address to an NGO Forum:

In societies where men are truly confident of their own worth, women are not merely 'tolerated', they are valued. Their opinions are listened to with respect; they are given their rightful place in shaping the society in which they live. (p. 124)

Thus, sincere partnership builds trust and confidence in place of fear.

\section{Violence and domestic violence}

If there is one issue that unites women all over the world, it is the threat of violence. From the helpless victim of war to the wife living in the supposed safety of her home, and from babies to grandmothers, women are living in increasingly dangerous times. (Munyakho 1998:1)

The UN Declaration on violence against women, which was formulated at the 4th UN World Conference on Women, held in Beijing, China in 1995, defines violence as:

... any act of gender based violence that results in or is likely to result in physical, sexual or psychological harm or suffering to women, including threats of such acts, coercion or arbitrary deprivation of liberty, whether occurring in public or private life. (cited in Scott 1999:338-339)

Amongst the many notorious forms of violence against women is rape. Rape is a serious tool used by some men to create obstacles for women for many reasons. Nussbaum (2000:30) cites how rape is used as a weapon against women crusading for political change. Much violence against women in Nigeria and other parts of the world result from the cultural prejudices and stereotypes in the baggage men hold about them. Elizabeth Amoah (1996:80) states that in many cultures a woman 'is seen as an object for unlimited access'. It is forgotten that a woman is more than her body; she is a person of dignity and worth, with an intellect, reason, a will to choose and her own desires.

The fact is that violence against women hinders progress, but working in partnership through 'facilitated dialogues' can foster new, respectful relationships, informed by a deepened understanding of the role of prejudice and stereotyping in discriminatory behaviour. Partnership and networking can help all to understand others better and to develop a commitment to fight against our personal, cultural and institutional prejudices and stereotypes such as classism, sexism and racism. This is not a task that women can achieve alone and we must point out that there are men, all over the world, who are against violence and the dehumanising treatment of women and who have started movements to stop it.

During Esther Onwunta's six-month study of human rights in Sweden in 2005, she had the opportunity to do field work in a Women's Help Centre in Falun. This is a centre where abused women are cared for and her experience in this centre confirms the fact that the issue of violence against women is not just an African affair but a global one. The centre was established more than 20 years ago when violence against women increased like wildfire in Sweden. Although Swedish women have been creating awareness through different organisations, Ester was told about an unprecedented achievement of 'The Men's Network'. According to the staff of the Women's Help Centre, a remarkable event took place in Piteå, a city in northern Sweden. In November 2004, a hunter was badly injured by a bear and all other hunters agreed that they should look for the bear and kill it. A week later, a woman was brutally murdered by her husband and a man asked: 'Should we all look for the man and kill him?' From there, they established an organisation to fight violence against women, which has been successful and has created a lot of awareness on the subject. This story points to the need for partnership to combat violence against women.

\section{Patriarchy and religious beliefs}

Patriarchy and its related discrimination against women is a major obstacle to partnership between men and women. The patriarchal system refers to power relations in society where men act in collusion in order to keep their dominant positions. The patriarchal structure in family relations has been mirrored in the structures of the Church and society. Women are expected to submit to patriarchal authority which denies them access to positions of authority. Thus, the system and its operation has oppressed women socially, politically, economically and even in the Church (Mwaura 
1999:56). Patriarchal structures exclude women from the decision-making processes, as shown through the empirical research discussed earlier. As Kang (2004) points out, this exclusion of women can also be because:

The patriarchal socialization of women has conditioned them to think, act, and re-act as second class members of the church and women are socialized to believe that they are good by accepting the dominant male view of how women ought to act. Women have internalized the patriarchal message that behaviour accepted by society, the institutional church, and its leaders is what constitutes a 'good woman' or a 'good Christian' and that any other conduct is displeasing to God. In this manner, women are not even aware that they are absorbing patriarchy into their systems. (p. 7)

Thus, in the Church and society, both culture and scriptural hermeneutics have conspired to consign women to the uncomfortable positions in which they find themselves today. Kanyoro (2002:17) therefore calls for a gender analysis of African culture and the practices of the Church in Africa.

Because this hermeneutic is needed now, we have to begin listening to women, for, according to Powers (2003):

Unless we listen, any action we may take in this area, no matter how well intentioned, is likely to bypass the real concerns of women and to confirm female condescension and reinforce male dominance. Listening, in a spirit of partnership and equality, is the most practical response we can make and is the foundation for our mutual partnership to reform unjust structures. (p. viii)

This therefore implies a cultural revolution and a radical overhauling of the entire hermeneutical enterprise we now know. What this also means is that both tradition and the Bible will remain sites of the struggle, as well as of the resources in that struggle. It is a task that must be faced with all the energies that we can muster so that true partnership can thrive in our communities. In the end, a dialogic approach is desirable to accommodate the varieties of modes of self-expression by women (Kolawole 1998:5). Men are not left out in this all important task because we know that men and women are enriched by coming together. By means of the relationship progress is made by keeping together, whilst it is working together that brings success! Indeed, it is not enough to keep together in the same society or church. It is not even a matter of one group handing over to, or taking over from the other. Men and women must work together in a sense of mutual respect and dignity. In this way we can learn to use our varied characteristics appropriately and to blend our different energies into the best mix for the most creative response to gender stereotyping. We all belong to the same human family regardless of our sexes. We should treat one another with respect and dignity so that the world will be a better place in which to live (Nelson 1978:102). This is about engaging in justice ministries and engendering gender justice that gives security to all.

\section{Insecurity}

The greatest source of insecurity is lack of belief in oneself, whilst the benchmark of security is the development of personal skills and ability. Security therefore comes not by trusting in any external power but by believing in, and operating with, the power of God that works in us as human beings. We know from history that many human oppressors have tried to destroy this sense of security in their fellow humans by robbing them of this confidence in self. Even today, there are still many people who do not want others to have this confidence which flows from a sense of selfesteem. They have continued to make their victims believe that they are nobodies and would want them to continue operating from that position in life. The apartheid legacy in South Africa, with which the society is still struggling today, is a clear example. Until the sense of insecurity is eliminated, there can be no sense of true partnership amongst the citizens in the country - whether they are men or women.

\section{Unequal access to resources}

Scholars have observed that political finance has a decisive effect on the very operations and the quality of democracy in every country (Ojo 2006:1). The Political party finance handbook cited by Ojo (2006) points out that:

In emerging democracies such as Nigeria, the highly monetized political culture coupled with the desperation of politicians to win elections at all cost has its attendant demand on huge election financial outlay. (p. 1)

According to Ojo (2006:1), most women in Nigeria do not have equal access to funds to enable them to participate actively in politics at all levels with their male counterparts. As a result, Nigerian politics, to a certain degree, remains the affair of men. Huge election financial outlay coupled with unequal access to funds is a great hindrance to women's partnership in Nigerian politics.

\section{Inadequate education}

It is evident that women do not share equal space with men in many spheres of life because of poor education and therefore this is another obstacle to true partnership. The value of formal education as a tool for individual and societal development is well recognised in many African countries. But the reality shows that women lag behind because of a number of factors. Mwaura (1999) has described women's conditions in Kenya:

The sluggish growth of the Kenyan economy and other factors such as repeated droughts, global recession, rising incidence of HIV / AIDS as well as ... factors such as low morale, lack of commitment and accountability, have all contributed to the stunting of educational progress. This has to some extent affected female education, although the gender ratio of 49:51 still remains unaffected. Relatively more girls than boys exit from primary school. (p. 50)

This scenario is not only seen in Kenya but also in many parts of Nigeria and South Africa, where women remain unequal to men with regard to formal education. An early exit from school with the resultant poor education partly explains why women trail behind men in many areas of human development, including partnership in public and private affairs. 


\section{Conclusion}

The following may be regarded as the summative points arising from this article:

- Development means different things to different people and involves people, on the one hand, and the factors of production and organisation on the other. However, the overriding normative principles in the development debate are the aspects of participation, empowerment and people-centeredness in development. Development is for people, amongst whom the entrapment of women and children as a result of culture, development theories and policies is the most pronounced.

- Development from a Christian perspective is normative as it is regarded as transformational development. According to this perspective, development is God's intention and engagement with the anti-creation to restore creation and people from what they are, into what they should be, according to his own purpose. Even the relation between men and women has been distorted by sin and needs to be restored into true partnership in our personal relationships and in our societal structures, as God has ordained it.

- Partnership is an imperative for progress in the Church and community. With particular reference to the Church, ministry as partnership is necessary not only for the Church as koinonia but also to enable the Church to provide a model for society, which is grappling with the same issues of shared responsibility and accountability between its leaders and its people.

- Genuine partnership thrives when the ideals of equality, mutuality, transparency, love, diversity and accountability are upheld and not compromised.

- Yet we know that true partnership is costly; there is no such thing as cheap partnership. And, being a costly venture, the price for partnership can only be paid by the brave and the courageous. Yet, the Church is called by God to affect transformation through genuine partnership in and through Jesus Christ - even in the sphere of development. Ultimately, men and women have this mutual vocation in life and in our created reality to deal with fear, violence, patriarchy, the sense of insecurity and other problems related to the anti-creation, which have hitherto hindered progress and made our partnership a dream yet to be realised. We are all called by God to be partners in our search for freedom and a better human community.

\section{Acknowledgements Competing interests}

The authors declare that they have no financial or personal relationship(s) which may have inappropriately influenced them in writing this article.

\section{Authors' contributions}

E.O. (University of Stellenbosch) was the doctoral student of K.T.A. (University of Stellenbosch), as such, she assisted in writing this article. She also did most of the basic research for it, including spending six months on a study programme in
Sweden, for which K.T.A. was the coordinator. Unfortunately, she passed away before this article could be published.

\section{References}

Abbey, R.T., 2001, 'Rediscovering Ataa Naa Nyonmo - The Father Mother God', in J.N. Njoroje \& W.M. Dube (eds.), Talitha Cum! Theologies of African women, pp. 140-157, Cluster Publications, Pietermaritzburg.

Allen, D., 1999, 'The role of the diaconate in urban Church revitalization', Mission Bulletin XIX(1), 3-7.

Amoah, E., 1996, 'Violence and women's bodies in African perspective', in J.N. Mananzan (ed.), Women resisting violence: Spirituality for life, pp. 80-86, Orbis Books, Maryknoll, NY.

August K.T., 1999, 'A curriculum for community development in Practical Theology', Mth Thesis, Department of Practical Theology and Missiology, University of Stellenbosch.

Baillie, S.M., 2002, Evangelical women in Belfast: Imprisoned or empowered, Palgrave, Basingstoke.

Bediako, K., 2004, Jesus and the Gospel in Africa: History and experience, Orbis Books, Maryknoll, NY.

Bosch, D.J., 1991, Transforming mission: Paradigm shifts in Theology of Mission, Orbis Books, Maryknoll, NY.

Bronkema, D., Lumsdaine, D. \& Payne, R.A., 1998, 'Foster just and sustainable economic development', in G. Stassen (ed.), Just peacemaking: Ten practices for abolishing war, p. 110, ThePilgrim Press, Cleveland, $\mathrm{OH}$.

Burkey, S., 1993, People first, Zed Books Ltd, London.

Carmen, R., 1996, Autonomous development: Humanizing the landscape: An excursion into radical thinking and practice, Zed Books Ltd, London.

Daly, L.K. (ed.), 1994, Feminist theological ethics, Westminster/John Knox Press, Louisville, KY.

Edet, R. \& Ekeya, B., 1989, 'Church women of Africa: A theological community', in M.M.V. Fabella \& M.A. Oduyoye (eds.), With passion and compassion: Reflections from the Women's Commission of the Ecumenical Association of Third World from theologians, n.p., Orbis Books, Maryknoll, NY.
The

Eme, N.N., 2004, Gender [in]justice and Nigerian women, Janai Press Enterprises, Minna.

Eyo, I.E., 1995, 'Leadership problems in Nigeria: A psychological analysis', in J.O.C Ozioko \& J.I. Onuoha (eds.), Contemporary issues in Social Sciences, n.p., Acena Publishers, Enugu.

Haddad, B., 2003, 'Gender development and faith: The Church and women's struggle to survive', Missionalia 31(3), 427-450.

Kabeberi-Macharia, J., 2004, 'Good governance: Ensuring participation of women and men in The SADC region', New Agenda: South African Journal of Social and Economic Policy, 14, 96-97.

Kang, N., 2004, 'The centrality of gender justice in prophetic Christianity and the mission of the Church reconsidered', paper presented at the NOTE Conference, Volmoed, South Africa, 22-26 March.

Kanyoro, M.R.A., 1996a, 'Feminist theology and African culture', in G. Wamue \& M Getui (eds.), Violence against women, pp. 4-12, Acton Publishers, Nairobi.

Kanyoro, M.RA., 1996b, 'God's calls to ministry: An inclusive hospitality', in M.R.A. Kanyoro \& N.J. Nyambura (eds.), Groaning in faith: African women in the household of God, pp. 149-160, Acton Publishers, Nairobi.

Kanyoro, M.R.A., 2002, 'Beads and strands: Threading more beads in the story of the Circle', in A.I. Phiri, D.B. Govinden \& S. Nadar (eds.), Her stories: Hidden histories of women of faith in Africa, pp. 15-38, Cluster Publications, Pietermaritzburg.

Kennedy, J., 1995, At the gates of the Forbidden City: Women of faith at Beijing, the ecumenical decade and beyond, Beijing and Beyond Book Project, Toronto.

Kolawole, M.E.M., 1998, 'Women's oral literature as a site for dynamic self-expression', in M.E.M Kolawole (ed.), Gender perceptions and development in Africa-A sociocultural approach, n.p., Arrabon Academic Publishers, Lagos.

Kopas, J., 1986, 'Jesus and women: Luke's Gospel', Theology Today 43(2), 192-202. http://dx.doi.org/10.1177/004057368604300205

McClure, J.S., 1995, The round table pulpit where leadership and preaching meet, Abingdon Press, Nashville, TN.

Munyakho, D., 1998, Gender review: Kenya's women and development quarterly, Signal Press, Nairobi.

Mwaura, P.N., 1999, 'Women in the democratization process', in L. Magesa \& Z. Nthamburi (eds.), Democracy and reconciliation: A challenge for African Christianity, n.p., Acton Publishers, Nairobi.

Ndungane, N., 2004, 'Prophetic Christianity and Church-State relations', in J.N.K. Mugambi \& F. Kuschner-Pelkmann (eds.), Church-State relations: A challenge for African Christianity, pp. 162-163, Acton Publishers, Nairobi.

Nelson, J.B., 1978, Embodiment: An approach to sexuality and Christian theology, Augsburg Publishing House, Minneapolis, MN.

Nussbaum, M.C., 2000, Women and human development: The capabilities approach, Cambridge University Press, Cambridge. 
Oduyoye, M.A., 2001, 'Significant contexts of African women's theology', in M.A. Oduyoye, Introducing African women's Theology, p. 86, Sheffield Academic Press, Sheffield.

Ojo, J., 2006, 'An examination of disclosure mechanisms for party finances', paper presented at the INEC-organised, Political Party Administration and Cost of Election (PACE) Conference, Transcorp Hilton Hotel, Abuja, 09 November.

Peskett, H. \& Ramachandra, V., 2003, The message of mission: The glory of Christ in all time and space, Intervarsity Press, Downers Grove, IL.

Powers, T.S.J., 2003, The call of God: Women doing theology in Peru, State University of New York Press, New York.

Rakoczy, S., 2004, In her name: Women doing theology, Cluster Publications, Pietermaritzburg.

Ramodibe, D., 1989, 'Women and men building together the Church in Africa', in M.M.V. Fabella \& M.A. Oduyoye (eds.), With passion and compassion: Reflection from the Women's Commission of the Ecumenical Association of Third World Theologians, n.p., Orbis Books, Maryknoll, NY.
Scott, C., 1999, 'The context for feminist theologizing: Violence against women/ Women against Violence', in P. Kumari (ed.), Feminist theologies: Perspectives and praxis, pp. 331-361, Gurukul Lutheran Theological College and Research Institute, praxis, p

Sheerattan-Bisnauth, P., 2004, 'Introduction', in Celebrating hope for life in fullness: Challenges for the Church. 3rd Women's Pre-council Report proceedings, n.p., World Alliance of Reformed Churches, Geneva.

Thangaraj, M.T., 1997, Relating to people of other religions: What every Christian needs to know, Abingdon Press, Nashville, TN.

United Nations, 1982, Discrimination against women, UN, Washington, DC.

Wickeri, P., 2004, 'Mission renewal in the context of globalization', Reformed World 54(3/4) 155-164.

Wilson, F. \& Ramphele, M., 1989, 'Uprooting poverty: South African challenge', report for the Second Carnegie Inquiry into Poverty and Development in southern Africa, David Philip, Cape Town. 